РОЗДІЛ 3

СЛОВ'ЯНСЬКІ МОВИ

UDC $81 ` 38+811.16$

DOI https://doi.org/10.32782/tps2663-4880/2021.19.1.15

\title{
LINGUOCULTURAL MOTIVATION OF SYNCHRONICITY / ASYNCHRONICITY OF MEDIA COMMUNICATION GENRES IN THE SLAVIC INFORMATION SPACE
}

\section{ЛІНГВОКУЛЬТУРНА МОТИВАЦІЯ СИНХРОННОСТІ / АСИНХРОННОСТІ ЖАНРІВ МЕДІЙНОЇ КОМУНІКАЦІЇ У СЛОВ'ЯНСЬКОМУ ІНФОРМАЦЙННОМУ ПРОСТОРІ}

\author{
Dergach D.V., \\ orcid.org/0000-0003-4215-3825 \\ PhD, \\ Associate Professor at the Department of Stylistics and Language Communication \\ Kyiv National Taras Shevchenko University
}

The article argues the linguistic and cultural motivation of the synchronicity / asynchronicity of media genre paradigm in Slavic communicative space. The author formulates genre paradox, actual for modern media space, that is solved through the current concept of 'format' (traditional genres of news, interviews, articles, etc.). Medialinguistic motivation of analyzed processes of communicative dynamics of modern genres (versions of shows, advertisements, media analytics, reviews, stories, giveaways, etc.) is also based on a range of semantic priorities of society development, the nature of its presence in the modern media sphere of the globalized world. Linguistic realization, architectonics, extralinguistic nature - all these traditional criteria of the functional status of the genre are taken into account in accordance with the format of the so-called 'genre Bible' that determines its communicatively oriented identity or adaptability in different countries. It is also mentioned current tendency to genre generalization of media communication, when the field of culture is not a criterion for linguistic and cultural identification of society. Emphasis is made primarily on the prescribed technical capabilities of programs and special applications, and genres, stylistic resources and content - quite typical characteristics for public communication.

The research focuses on the functional differentiation of 'traditional' and 'new' media that represent already established communicative models or successful genre formats that generally determines the criteria of identity in dynamics of Slavic media. The genre synchronicity / asynchronicity of their status and development was interpreted on the material of modern authoritative national print and television media (in Ukraine, Poland, Slovak Republic, Czech Republic, Bulgaria, Serbia) and social networks. The thesis on the globalization dimension of the dynamics of mass communication is actualized. Its professional interpretation is effectively identified in the constructs of the geolinguistic paradigm.

Key words: media, Slavic media, genre, media genres, media genre theory, linguistic and cultural motivation.

У статті аргументовано лінгвокультурологічну мотивацію синхронності/асинхронності медіажанрової парадигми у слов'янському комунікативному просторі. Автор формулює й інтерпретує актуальний для сучасного медіапростору жанровий парадокс, пов'язаний із сучасним поняттям «медійний фрормат». Медіалінгвістична мотивація аналізованих процесів комунікативної динаміки сучасних жанрів (інваріанти шоу, реклами, медіааналітики, огляди, сюжети, сторіз, гівевеї та ін.) коментується в контексті смислових пріоритетів розвитку суспільства, їх ідентифрікації в сучасній медіасфері глобалізованого світу. Мовна реалізація, архітектоніка, екстралінгвістичний характер - усі ці традиційні критерії функціонального статусу жанру враховуються відповідно до фрормату так званої «жанрової Біблії», що визначає його комунікативно орієнтовану ідентичність чи адаптивність у різних країнах. Аргументується й сучасна тенденція до жанрового узагальнення медіакомунікації, коли сфера культури не є критерієм лінгвокультурної ідентифікації суспільства. Акцент робиться, насамперед, на прописаних технічних можливостях програм і спеціальних додатків, а жанри, стилістичні ресурси та контент - типові характеристики для публічної комунікації.

Дослідження зосереджено на функціональній диференціації «традиційних» і «нових» медіа, що представляють уже усталені комунікативні моделі чи успішні жанрові формати, що загалом визначає критерії ідентичності в динаміці слов'янських медіа. Жанрову синхронність/асинхронність їх статусу та розвитку інтерпретовано на матеріалі сучасних авторитетних національних друкованих і телевізійних ЗМІ (в Україні, Польщі, Словаччині, Чехії, Болгарії, Сербії) та соціальних мереж. Актуалізовано тезу про глобалізаційний вимір динаміки масової комунікації, а її професійна інтерпретація ефективно ідентифікована в конструкціях геолінгвістичної парадигми.

Ключові слова: медіа, слов'янські медіа, жанр, медійні жанри, медійна жанрологія, лінгвокультурна мотивація.

Introduction. Functional and stylistic differentiation of literary language testifies to its developed resource and potential in ensuring social interaction. It is determined by extralinguistic factors that motivate the researcher systematically to analyze the dynamics of communicative categories. They can be defined as universal for the identification of literary language, and some of them are invariant in the discursive dynamics of the linguistic and cultural field. 
One of such categories is the genre - form of verbal interaction, with special architectonics - in accordance with the tasks and functions of communication. In turn, media genre is inherently motivated by an extensive system of techniques and methods of social communication, adapted to the linguistic and cultural dominants of the evolution of social priorities. Thus, media sphere realizes the contrasting nature of the synchronicity / asynchronicity of the core and the periphery of its genre system. Both intrinsically and in the discourse of functional and stylistic parallels in closely related languages, in particular in Slavic cultural space. In fact, it determines the relevance of the chosen research subject.

On the one hand, such genre paradox can be solved through the current concept of 'format' (traditional genres of news, interviews, articles, etc.). But on the other hand - the medialinguistic motivation of the analyzed processes of communicative dynamics of modern genres (versions of shows, advertisements, media analytics, etc.) is based on a range of semantic priorities of society development, the nature of its presence in the modern media sphere of the globalized world. Thus, it quite transparently motivates the linguistic and cultural dynamics (quite constant for non-media spheres) of the genre category in media discourse, which is effectively reflected in the style and functions of literary language in public communication.

Actuality of the investigation subject is deepened by the cross-cultural dynamics of modern mass media, including the Slavic space. It, in particular, motivates the emergence of new or renewal of optimal (according to the time and space of culture) forms of communication - genres. Mostly adopted from the Anglo-American linguistic and cultural reality, they reflect the state and status of the mass language consciousness, reflect the values, priorities and prospects of society. After all, we are talking about the specifics of information, the features of its verbalization, functions, that, according to the high ratings of specific forms of perception and reflection of the audience, can be defined as paternalized. They can be assimilated by the mass linguistic consciousness as genre samples and templates, successfully processed by a certain culture, and therefore, they have a communicative basis for adopting to another linguistic and cultural reality - for its successful dynamics.

In this case, it is actual (and not represented in modern media linguistics science) from the research point of view to analyze the genre system of 'traditional' and 'new' Slavic media, that indicate the synchronicity / asynchronicity of media development in these countries. For the objectivity of professional (medialinguistic) interpretation of a certain subject matter, television, newspaper, virtual contexts of media development in different communicative segments of the Slavic space - Ukraine, Slovak Republic, Czech Republic, Poland, Bulgaria, Serbia were chosen. It will allow to identify and analyze the 'points' of communicative (linguistic, stylistic) interaction / non-interaction of the linguistic and cultural reality of different Slavic countries. Such research accent forms the main aim and task of current investigation.

So, "cross-country comparison revealed a number of major differences concerning both the basic aspects of personalization communication, such as the type of language used..., as well as the interpretation of more specific concepts, such as data storage" [1], realized in the media genres.

Material: texts and content of national newspapers and TV channels of social and political orientation, social networks where the functional resource of media communication is manifested in various genres, the linguistic, cultural and stylistic status of which is the object of analysis.

\section{Communicative motivation of genre format in modern mass media}

Media communication defines, verbalizes the mass language consciousness, influences it and, consequently, identifies social values and priorities. It is manifested in the system of linguistic and extralinguistic factors, relevant to the specific analysis of the media space.

In particular, we are talking about language units, genres, content that provide the dynamics of media communication, indicate its status, functional resource and potential. As a result, a synchronous system of social and communicative reality is being organized - in the context of information as a resource of knowledge about society, verbalized in the media. It is logical that the national media (through genres, content, information and analytical reasoning) are marked by the individual synchronicity of these factors. Consequently, they will develop asynchronously in relation to the media systems of other countries. In particular, it is manifested in the asymmetric dynamics of the genre core and periphery that indicate different approaches to the content in the media of the country.

Modern media communication is based on the dynamics of globalization processes, one of the results of which is the tendency to open information and language borders. The information itself is not disseminated in a linear, limited format for locally identified recipients, but instantly for a mass audience. It became possible in the context of the technical revolution that digitalizes mass communication - 
'through the introduction of digital technologies into the production processes of the forms' [2, p. 103] in the media sphere. Thus, it simplifies and develops the formats of access to media information. This trend reveals the multi-vector influence of the language, genres, media functions of one country on others. As a result, the geolinguistic dimension of media communication analysis is updated. It is, first of all, a professional interpretation of such influence by the languages of international communication (in particular, English) and the cultures, that they represent, on the world information space and the processes of its dynamics. In this case, it can be argued that today's media are developing on the principle of analogy, when the concept of 'format' is becoming more and more relevant. Therefore, it is quite reasonable to say that the types and genres of media communication are "products of social history and the continuous development of media technologies, including their adaptations to existing media' [3, p. 67].

The synchronicity of genre systems in the Slavic media is confirmed not only and not so much by the actualization of the same genres in the media space. But first of all according to their linguistic realization, architectonics, extralinguistic nature. All these criteria of the functional status of the genre are taken into account in accordance with the format of the so-called 'genre Bible' that determines its communicatively oriented identity or adaptability in different countries.

According to Michel Rodrigue, 'father of formats', the essence of the 'Bible' is in the transfer of experience. 'Bible format' is a great opportunity for the producer of the original show to communicate with the producer, who will adapt it, and express all his passion for the format, investing it in describing the essence of the project and why it was created and what it eventually achieved.

\section{Synchronicity / asynchronicity of Slavic tel- evision media}

In general, the communicative orientation on Europe and the United States (in a less degree on Asian countries) violates the asynchronous (individual for each linguistic and cultural field) context of media dynamics, including the genre system. There is a total / global synchronization of the communicative (in terms of language, genres, functions) reality of the media field, which, as a result, loses national borders and functions as a single media space. We can talk about the narrowing and gradual disappearance of the criteria of authorship of the media text, the existence of so-called 'author's media' because extraand intralingually genre paradigm of the media quite dynamically acquires characteristics of formatting. It explains the typical representation of adapted media genre formats that, having ratings and resonance in one country, are bought by other countries to increase communicative ratings in the media field of cultural space.

In particular, television formats are actively developing, updated in the media space because they have analogues in different countries and appear as a kind of cultural pattern of development and dynamics of media communication.

\begin{tabular}{|c|c|c|}
\hline \multirow{2}{*}{ Country } & $\begin{array}{c}\text { Original format “Strictly Come Dancing”, } \\
\text { Great Britain, 2004) }\end{array}$ & Seasons \\
\hline Ukraine & Taнці з зіркамu & $2006,2007,2011,2017-2021$ \\
\hline \multirow{2}{*}{ Poland } & Taniec z Gwiazdami & $2005-2011$ (13 seasons) \\
\cline { 2 - 3 } & Dancing with the Stars - Taniec z Gwiazdami & $2014-2021(12$ seasons) \\
\hline Slovak Republic & Let's Dance & $2006,2008-2011,2017$ \\
\hline \multirow{2}{*}{ Czech Republic } & $\begin{array}{c}\text { StarDance ...když hvězdy tanči } \\
\text { (StarDance ...when stars dance) }\end{array}$ & $2006-2008,2010,2012,2013,2015$, \\
\hline Bulgary & Dancing Stars & $2016,2018,2019,2021$ \\
\hline Serbia & Ples sa Zvezdama & $2008,2009,2013,2014$ \\
\hline
\end{tabular}

\begin{tabular}{|c|c|c|}
\hline Country & $\begin{array}{l}\text { Original format “Got Talent", } \\
\text { Great Britain, 2006) }\end{array}$ & Seasons \\
\hline Ukraine & Украӥна має талант & 2009-2015, 2021 \\
\hline Poland & Mam talent! & $2008-2019,2021$ \\
\hline \multirow[b]{2}{*}{ Slovak Republic } & Slovensko má talent & 2008 \\
\hline & Česko Slovensko má talent & $\begin{array}{c}2010-2013,2015,2016,2018,2019, \\
2021\end{array}$ \\
\hline Czech Republic & Česko Slovensko má talent & $\begin{array}{c}2010-2013,2015,2016,2018,2019, \\
2021\end{array}$ \\
\hline Bulgary & България търси талант & $\begin{array}{c}2010,2012,2014-2016,2019,2021, \\
2022\end{array}$ \\
\hline Serbia & Ја имам таленат! & $2009,2011-2013,2016-2017$ \\
\hline
\end{tabular}


Закарпатські філологічні студії

\begin{tabular}{|c|c|c|}
\hline Country & $\begin{array}{c}\text { Original format “Masked Singer”, Masked Singer's King, } \\
\text { South Korea, 2015) }\end{array}$ & Seasons \\
\hline Ukraine & Macкa & $2020-2021$ \\
\hline Slovak Republic & Zlatá maska & 2020 \\
\hline Czech Republic & Zlatá maska & 2020 \\
\hline Bulgary & Маскиранияm певец & $2019-2021$ \\
\hline
\end{tabular}

\begin{tabular}{|c|c|c|}
\hline Country & $\begin{array}{c}\text { Original format "MasterChef", } \\
\text { Great Britain, 1990) }\end{array}$ & Seasons \\
\hline Ukraine & MaйстерШеф & $2011-2021$ \\
\hline Poland & MasterChef & $2012-2021$ \\
\hline Bulgary & MasterChef България & $2015-2021$ \\
\hline
\end{tabular}

Adaptation of the format involves communicative and genre synchronization in all countries according to different criteria, when it comes to the absolute analogy of the project name (at least in the root morpheme: 'dancing', 'star', 'talent', 'mask', 'master', 'chef' etc.), their architectonics, musical design, internal rules, style of scenery, even period of creation and translation of etc.

In turn, the national format, with a lack of information and media resonance, usually has low ratings, and therefore falls out of the system that identifies the current genre paradigm of the media in a particular linguistic and cultural space («Україна сльозам не вірить» / 'Ukraine does not believe in tears'). On the other hand, the original Ukrainian projects «Ревізор» / 'Inspector', 'Орел та решка' / 'Eagle and Tail', deepening the entertainment function of show genres in a cognitive context, received the undisputed support of the mass audience.

3. Genre system of 'traditional' media in the Slavic linguistic and cultural space

Elements of the genre paradigm of 'traditional' media are present in all media without exception, as they are a fundamental resource of information about the world. They operate on a similar principle, and therefore their invariants in the genre and stylistic implementation are characterized by similar language, architectonics and content.

\subsection{Information article}

Linguistic and stylistic synchronization of media information is observed in the nature of the traditional (and hence constant) genre of information article. In the analyzed Slavic media, it can be seen, first of all, in the architectonics of the text, the means of argumentation and the linguistic representation of the transmitted meaning of the information. In particular, it is a typical linear model of a declarative sentence (with a direct order of words), which states one or another fact mostly in the semantics of verb constructions of the past or future tenses. That is, the attention of recipients is focused on the semantic centers 'what has been done', 'what has happened', 'what will be done', without detailing and indicating the causes and consequences.

\subsection{Media analytics}

Media analytics, also implemented in the genre of the article, is based on a functionally and stylisti-

\begin{tabular}{|c|c|}
\hline Country & Information article genre \\
\hline $\begin{array}{l}\text { Ukraine } \\
\text { («Дзеркало тижня», } \\
\text { https://zn.ua) }\end{array}$ & $\begin{array}{l}\text { У новому сезоні Украӥнської хокейної ліги виступлять вісім клубів. Серед учасників } \\
\text { буде один новачок (06.09.2021). } \\
\text { Археолог-новачок знайшов майже } 1 \text { кг золотих артефактів VІ століття в Данії } \\
(06.09 .2021) \text {. } \\
\text { На Київ насувається гроза, аз } 2 \text { вересня різко похолодає. Особливістю погоди } 2 \text { вересня } \\
\text { стане шквальний вітер і дощі (01.09.2021). } \\
\text { Польща відкриє на кордоні з Украӥною новий пункт пропуску. Будівництво трива- } \\
\text { тиме 4 роки (03.09.2021). }\end{array}$ \\
\hline $\begin{array}{l}\text { Poland } \\
\text { (“Gazeta Wyborcza", } \\
\text { https://wyborcza.pl) }\end{array}$ & $\begin{array}{l}\text { Microsoft podal date premiery Windows 11. Darmowa aktualizacja nie dla wszystkich } \\
\text { (31.08.2021). } \\
\text { Chiny ograniczaja dzieciom czas na gry online do trzech godzin tygodniowo (30.08.2021). } \\
\text { Netflix wchodzi do Polski z mobilnymi grami (28.08.2021). }\end{array}$ \\
\hline $\begin{array}{l}\text { Slovak Republic } \\
\text { ("Nový Cas"،, } \\
\text { https://www.cas.sk) }\end{array}$ & $\begin{array}{l}\text { Pápež František príde už o pár dni: Na celom Slovensku sa rozoznejú zvony (06.09.2021). } \\
\text { Na ceste R1 sa pripravte na obmedzenia: Tento úsek sa bude opravovat' (06.09.2021). }\end{array}$ \\
\hline $\begin{array}{l}\text { Bulgary } \\
\text { (“Труд”, https://trud.bg) }\end{array}$ & $\begin{array}{l}\text { Гори } 250 \text { декара борова гора в Кирковско (06.09.2021). } \\
35 \text { общини получават нови училищни автобуси (16.08.2021). } \\
\text { Влакове заквсняват заради жегата (02.08.2021). } \\
\text { Рекордните 40,9 градуса на сянка измериха в Ловеч (11.08.2021). }\end{array}$ \\
\hline
\end{tabular}


cally more variable language resources. Its semantic specificity presupposes the deepening of the statement of fact by evaluative argumentation, which can be actualized in the meaning of a single word, phrase or in the sentence structure. Analytics are often found in complex interrogative constructions (or in interrogative intonation - in the oral form of media communication), which specifically or rhetorically violate a particular problem, that is commented or solved in the text of the analytical article. In contrast to the information article, focused on the actualization of verb semantics, analytical texts mostly have a nominative nature: nouns, adjectives of qualuty with the value of evaluation, numerals, percentages, which indicate the number - a certain resource of analytics.

\begin{tabular}{|c|c|}
\hline Country & Analytic article genre \\
\hline $\begin{array}{c}\text { Ukraine } \\
\text { («Дзеркало тижня», } \\
\text { https://zn.ua) }\end{array}$ & $\begin{array}{l}\text { Стрибнути в майбутнє: Емінем, ТікТок і } 30 \text { років Незалежності України. Про новий } \\
\text { світовий порядок та що робити, аби остаточно в ньому не загубитися (24.08.2021). } \\
\text { Кадрова криза в судах. Статистика, причини, прогноз. Що може зробити влада для } \\
\text { максимально швидкої імплементації законів щуодо ВККС та ВРП і розблокування судо- } \\
\text { вої системи (02.08.2021) } \\
\text { Бюро економічної безпеки: амнезія чи саботажс? (16.05.2021). } \\
\text { Локалізуймося, бо ми того варті. Що дасть Україні “локалізаџія” в публічних закупів- } \\
\text { лях (21.07.2020). }\end{array}$ \\
\hline $\begin{array}{c}\text { Poland } \\
\text { (“Gazeta Wyborcza”, } \\
\text { https://wyborcza.pl) }\end{array}$ & $\begin{array}{l}\text { Koronawirus - podsumowanie tygodnia. COVID-19 wraca z wakacji (03.09.2021). } \\
\text { Zieloni alarmuja: Morze Battyckie umiera (05.09.2021). } \\
\text { PiS gra o wszystko. Co zostanie z 'Polskiego ładu', kiedy projekt trafi do Sejmu? Na razie } \\
\text { przeciw jest nawet Kościót (03.09.2021). } \\
\text { Puszcza Amazońska pada w ogniu pożarów i polityki (03.09.2021),. } \\
\text { Zobacz, czy morze cię zaleje. Nowe prognozy naukowców (31.08.2021). }\end{array}$ \\
\hline $\begin{array}{c}\text { Slovak Republic } \\
\text { ("Nový Cas“, } \\
\text { https://www.cas.sk) }\end{array}$ & $\begin{array}{l}\text { Návrh konzilia podporujú všetky koaličné strany: Dôjde k zmene pravidiel? (06.09.2021). } \\
\text { Plánujú vymenit' Igora Matoviča ako lídra strany? Heger v tom má jasno (05.09.2021). } \\
\text { Budeme sa očkovat' tretou dávkou vakcíny proti COVID-19? EMA prehovorila (06.09.2021). } \\
\text { Situácia v košickej nemocnici sa podobá na minulú jeseñ. Počet pacientov stúpa, dominujú } \\
\text { neočkovaní (06.09.2021). }\end{array}$ \\
\hline $\begin{array}{c}\text { Bulgary } \\
\text { (“Tруд”, } \\
\text { https://trud.bg) }\end{array}$ & $\begin{array}{l}\text { Левите водят с 5\% пред Меркел (06.09.2021). } \\
\text { Румен Радев: Време е да се излекуваме от комплексите за политическа обреченост } \\
(06.09 .2021) . \\
\text { Защо ДПС настоява да бъде разкрита иялата информация за Пеевски и защо това } \\
\text { толкова плаши кръга „Капитал“(03.09.2021). } \\
\text { Харвард не е това, което беш (01.09.2021). }\end{array}$ \\
\hline
\end{tabular}

\subsection{Interview}

The traditional genre of interview in the media space, in particular, in the Slavic countries, is also not determined by culturally oriented factors. First of all, due to the fact that the interview is a well-established, crystallized form, a method of collecting and processing information (often precedent) that performs constant functions, and therefore its resource again synchronizes media style, content and context in different countries. It is manifested in the architectonics of the interview genre, that is built in several typical models of direct, indirect speech, relevant to the analyzed media: 'interviewer + thesis / quote / argument'; 'thesis + interviewer + argument'; 'thesis + genre + interviewer'.

\begin{tabular}{|c|c|}
\hline Country & Interview genre \\
\hline $\begin{array}{c}\text { Ukraine } \\
\text { («Дзеркало тижня», } \\
\text { https://zn.ua) }\end{array}$ & 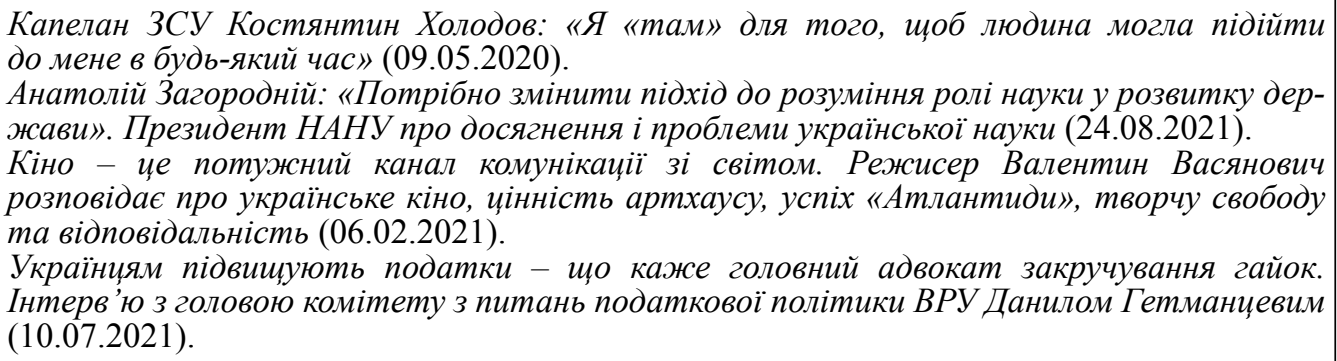 \\
\hline $\begin{array}{c}\text { Bulgary } \\
\text { («Tрyд», } \\
\text { https://trud.bg) }\end{array}$ & $\begin{array}{l}\text { Проф. Денков: В сряда ще са ясни мерките за училищата, щее са свързани най-вече } \\
\text { смаските (06.09.2021). } \\
\text { Режисьорът Стефан Командарев пред «Труд»: Най-използвана клинична пътека за } \\
\text { пациентите в България е тази до банкомата (02.09.2021). } \\
\text { Политологът д-р Станислав Бачев пред «Труд»: България е във война със себе си. Жънем } \\
\text { това, което сме посели (03.09.2021). } \\
\text { Председателят на Софийския форум за сигурност Йордан Божслов пред «Труд»: } \\
\text { Победата на талибаните ще породи бежанска криза и тероризъм (31.08.2021). }\end{array}$ \\
\hline
\end{tabular}




\subsection{Media review}

Media review provides an author's reflection on a film, phenomenon, event, exhibition, concert, play, etc., and therefore mostly a connected with an artistic theme. It, in turn, synchronizes (regardless of the country) in such media texts usage of appropriate terminology, means of modality and value, which gives them relief in architectonics and perception. It is safe to say that in the system of analyzed relatively traditional genres of media communication, media review is one of the few genres that is determined by the field of culture, systematically verbalizes the author's idiosyncrasy, localizes the mass audience with artistic aesthetic issues. Therefore, such texts are significantly less in the system of media content, which, in particular, is reflected in the table.

\begin{tabular}{|c|c|}
\hline Country & Media review genre \\
\hline $\begin{array}{l}\text { Ukraine } \\
\text { («Дзеркало тижня», } \\
\text { https://zn.ua) }\end{array}$ & $\begin{array}{l}\text { Варваріяда: від очікування до пошуків. Два романи, поєднані одним віршем (05.09.2021). } \\
\text { Між героїкою і посттравмою. Про украӥнський документальний комікс (18.05.2021). } \\
\text { Уся оперна Свропа в Театрі оперети (20.12.2019). }\end{array}$ \\
\hline $\begin{array}{l}\text { Poland } \\
\text { ("Gazeta Wyborcza", } \\
\text { https://wyborcza.pl) }\end{array}$ & $\begin{array}{l}\text { To wtedy Diana podjęła decyzję o rozwodzie. Ten film przypomina ożywianie ducha } \\
(03.09 .2021) \text {. } \\
\text { Dlaczego Marvel już nie zachwyca? Ale zaczyna się świetnie (03.09.2021). }\end{array}$ \\
\hline $\begin{array}{l}\text { Bulgary } \\
\text { («Tpyд», } \\
\text { https://trud.bg) }\end{array}$ & $\begin{array}{l}\text { Сериал разказва шеметната история на Карл Лагерфелд (05.09.2021). } \\
\text { «Малкият принщ» гостува в Jоу Station с гласа на Димо от P.I.F. (02.09.2021). } \\
\text { Митична епоха оживя на фестивала «Тракийски мистерии» в Несебър (31.08.2021). } \\
\text { Нов турски сериал се заканва да завладее света (27.08.2021). }\end{array}$ \\
\hline
\end{tabular}

\subsection{News}

Analyzed genre system of news in different Slavic countries indicates the synchronicity of the formats of morning and evening, weekly and annual news, which in ascending gradation deepen their information and analytical functional resource.

The informative and entertaining nature of news is also synchronized in the media space, in particular in Slavic, with such a format of news representation as infotainment. It is relevant mostly for the morning time, when it comes optimal to inform in a 'light' format. News here is presented not in the traditional linear presentation, but in a dynamic communicative model that combines various news information (reviews, analytics, media reviews, horoscopes, weather forecast, recipes, etc.), interactive communication, lives, interviews, discussions in the studio, blitz polls, etc. This genre format is recognized by psychologists as optimal for the beginning of the day, and therefore it is systematically / synchronously represented in the media system of the Slavic countries.

\begin{tabular}{|c|c|}
\hline Country & Morning news (infotainment) \\
\hline Ukraine & «Сніданок з 1+1», «Твій день», «Підйом», «Доброго ранку, Украӥно!»» \\
\hline Poland & "Pytanie na śniadanie - pobudka", "Nowy dzień", "Dzień Dobry”. \\
\hline Slovak Republic & “Ranné správy RTVS”, “Teleráno”, “Ranné noviny”. \\
\hline Bulgary & «Денят започва», «100\% будни», «Здравей, България - сутрешен блок». \\
\hline
\end{tabular}

Conclusions. Research prospects. The communicative, genre reality of the modern mass media field ambiguously reacts on the challenges of globalization. On the one hand, the author's individualization, especially in media, is seen as a reference form of personal, analytical perception of the world. On the other hand, the media format transforms the information space into a unified system of communication (particularly in the Slavic world), differentiated more by genre criteria than by national or linguistic and cultural ones. It is evident in the emergence and communicative dynamics of genres of virtual ('new') media, represented in various social networks, microblogs, vlogs (Facebook, Instagram, YouTube, Twitter, TikTok), etc. They operate on unified principles, criteria (using typical linguistic and stylistic means of media communication), influencing the system of 'traditional' media. So, there is a tendency to genre generaliza- tion of the model of virtual communication, when the field of culture is not a criterion for linguistic and cultural identification of society. Emphasis is placed primarily on the prescribed technical capabilities of programs and special applications, and genres, stylistic resources and content - quite typical characteristics of such public communication. Genres, first of all, are thematically, linguistically and functionally oriented on the mass audience, and therefore do not depend on the linguistic and cultural subjectivity of the analysis of media communication. The deepening of cross-cultural comparative studies of the genre system of modern media determines the prospects for the study of precedent meanings and contexts that affect the synchronization of media reality in a globalized world and verbally define the values of modern society as objects of further fundamental investigations in media linguistics. 


\title{
REFERENCES:
}

1. Bastian, M. et al. Explanations of news personalisation across countries and media types. Internet Policy Review. № 9(4). 2020. URL: https://doi.org/10.14763/2020.4.1504 (accessed: 29.09.2021).

2. Darley A. Visual digital culture. Surface play and spectacle in new media genres. London; New York, 2000. $236 \mathrm{p}$.

3. Gálik M., Vogl A. Pluralism of Media Types and Media Genres. Media Pluralism and Diversity. Palgrave Global Media Policy and Business / Valcke P., Sükösd M., Picard R.G. (eds). London, 2015. URL: https://doi. org/10.1057/9781137304308_4 (accessed: 18.10.2021).

УДК 811.111'373

DOI https://doi.org/10.32782/tps2663-4880/2021.19.1.16

\section{РОДИННЕ КОЛО ЯК ЛІНГВОКУЛЬТУРНА ПАЛІТРА (НА МАТЕРІАЛІ НАРОДНИХ ПІСЕНЬ БОЛГАР УКРАЇНИ)}

\author{
THE FAMILY CIRCLE AS A LINGUOCULTURAL SWATCH \\ (A CASE STUDY OF THE FOLK SONGS OF THE BULGARIANS IN UKRAINE)
}

\author{
Малаш О.В. \\ orcid.org/0000-0002-5726-5646 \\ кандидат філологічних наук, \\ молодиий науковий співробітник \\ Інституту мовознавства імені О.О. Потебні \\ Начіональної академії наук України
}

\begin{abstract}
Стаття присвячена традиційній болгарській родині в народнопоетичних текстах болгар-переселенців, нащадки яких проживають в Одеській, Запорізькій, Миколаївській областях та в Криму. Родину розглянуто як масштабний символ, концепт болгарської культури, носії якої відірвані від історичної батьківщини. Болгарська етноспільнота в Україні утворилася внаслідок переселення болгар із метрополії до центрального та південного регіонів у другій половині XVIII - першій половині XIX ст. під час османського панування на Балканському півострові. Болгари-переселенці принесли з собою великий масив усної народної творчості, яка може слугувати для різноспрямованих досліджень болгарського мовного острова. Джерельною базою цих студій стали збірники болгарських пісень за редакцією С. Цветка, Н. Кауфмана, О. Червенко, Л. Ноздриної, записані ними у другій половині XX - на початку XX ст.

Авторка зосереджує увагу на лінгвістичному портретуванні членів родини в родинно-побутових, родинно-обрядових, героїчних, гайдуцьких, жартівливих піснях та піснях із міфологічною фабулою. У статті проаналізовано лексичні засоби створення стереотипних образів матері, батька, подружжя, дітей та інших родичів, поведінка яких у фольклорних сюжетах $€$ яскравим маркером болгарської лінгвокультури. Встановлено, що в межах концепту «родина» мовні портрети всіх персонажів болгарської народної пісні характеризуються дуальністю; лексичні та фрразові одиниці, використані в текстах, залежно від сюжету потрапляють до кардинально протилежних семантичних полів - «життя» та «смерть». Деякі мовні портрети, що визначаються особливою внутрішньою суперечливістю, викривають антигуманність патріархату, його несумісність із сенсом існування сім'ї. Інші мовні образи демонструють вітальність, підкреслюючи ії важливість для існування майбутнього.
\end{abstract}

Ключові слова: болгарська мова, болгари в Україні, лінгвокультурологія, мовний портрет, народна пісня, лексика спорідненості

The article deals with the traditional Bulgarian family in folk poetry texts of the Bulgarian migrants, whose descendants is currently living in the regions of Odessa, Zaporizhia, Mykolaiv, and in the Crimea. The traditional family is investigated as a great symbol, concept of the Bulgarian culture, the bearers of which are separated from their historical motherland. The Bulgarian ethnical society has been created due to the migrations of Bulgarians from the mother country to the central and south regions in the last half of the $18^{\text {th }}-$ first half of the $19^{\text {th }} \mathrm{c}$. The Bulgarian migrants have brought here the huge collection of the oral folk arts, those can be useful for diverse studies in the Bulgarian language island. The sources of this investigation are Bulgarian songbooks edited by S. Tsvetko, N. Kaufman, O. Chervenko, L. Nozdrina, which songs was recorded by these scholars in the last half of the $20^{\text {th }}$ - the early $21^{\text {st }} \mathrm{C}$.

The author is focusing on the lingual portraits of family members in the folk songs of different genres. Here we are analyzing he lexical modes of creating images of mothers, fathers, marriage partners, kids and other relatives, whose behavior in the folklore narratives is a vivid marker of the Bulgarian linguistic culture. It is established that the lingual portraits of all the characters of the Bulgarian folk song exhibit their duality. The lexical units and their compositions used in the text are included to the oppositional semantic fields - "life" and "death". A few lingual portraits, in those the internal contrariety is strongly expressed, are convicting an exclusive antihumanity of the androcracy, the incongruity between it and the sense of the family existence. Other lingual images are highlighting the vitality; emphasize its importance for the future.

Key words: Bulgarian language, Bulgarians in Ukraine, linguoculturology, lingual portrait, folk song, kinship vocabulary. 